\title{
JURISDICTION OVER SUITS AGAINST FOREIGN CONSULS IN THE UNITED STATES
}

\section{R. G. SURridge $\div$}

The question of the status of foreign consuls in the courts of the United States ${ }^{1}$ has recently brought to light an interesting conflict between two fairly well established principles of jurisdiction: the first, that federai courts have no jurisdiction over cases involving problems of domestic relations, particularly divorce and alimony; the second, that the federal courts have exclusive jurisdiction over all suits against foreign consuls.

Foreign consuls are not entitled to the immunities of public ministers from legal process ${ }^{2}$ but on the contrary have been held subject in the United States to the ordinary jurisdiction of the courts. ${ }^{3}$ However, one of the major problems concerning foreign consuls in the United States has been to determine which system of courts, state or federal, should have jurisdiction over suits against them. The importance of this problem is evidenced by the fact that it is dealt with in the Constitution of the United States, wherein the Supreme Court is given original jurisdiction over "all Cases affecting Ambassadors, other public Ministers, and Consuls".4 Jurisdiction over suits against consuls has also been the subject of legislation by Con-

†A.B., I929; J.D., I930, University of Michigan; LL. M., 193I, Harvard University ; Carnegie Fellow for International Law at Ecole Libre des Sciences Politiques, Paris; member of the Order of the Coif, and of the District of Columbia Bar.

1 The general question of the status of foreign consuls in the United States is discussed by Puente, Amenability of Foreign Consuls to Judicial Process in the United States (I928) 77 U. of PA. L. Rev. 447.

Caldwell v. Barclay, I Dall. 305 (U. S. I788); I OP. ATr'y Gen. 4 I (I794), 406 (1820); U. S. CoNsular ReG., I896, p. 27.

${ }^{3}$ Coppell v. Hall, 7 Wall. 542 (U. S. I868) ; Gittings v. Crawford, Fed. Cas. No. 5465 (C. C. Mo. I838) ; Lorway v. Lousada, Fed. Cas. No. 8517 (D. C. Mass. I866) ; Sagory v. Wissman, 2 Ben. 240, Fed. Cas. No. I2, 2 I7 (C. C. S. D. N. Y. I868); I Op. Atr'y Gen. 406 (I820) ; 7 Or. ArT'y GEN. 367, 384 (1855) ; Commonwealth v. Kosloff, 5 S. \& R. 545 (Pa. I816); Clarke v. Cretico, I Taunt. 106 (I808); Viveash v. Becker, 3 M. \& S. 284 (I8I4). The legal status of foreign consuls was well summed up by Attorney General Butler in I835: "A consul is not such a public minister as to be entitled to the privileges appertaining to that character: nor is he under the special protection of the law of nations. He is entitled to privileges to a certain extent, such as for safe conduct; but he is not entitled to the jus gentium. Vattel thinks that his functions require that he should be independent of the ordinary criminal jurisdiction of the country; and that he ought not to be molested, unless he violate the law of nations by some enormous crime; and that, if guilty of any crime, he ought to be sent home to be punished. But no such immunities have been conferred on consuls by the modern practice of nations; and it may be considered as settled law, that consuls do not enjoy the protection of the laws of nations any more than any other persons who enter the country under a safe conduct. In civil and criminal cases, they are equally subject to the laws of the country in which they reside." 2 OP. ATr'y GEN. 725 (I835).

" The judicial Power shall extend to all Cases in Law and Equity arising under this Constitution, the Laws of the United States, and Treaties made, or which shall be made under their authority; . . . to all cases affecting Ambassadors, other public Ministers, and Consuls;

"In all Cases affecting Ambassadors, other public Ministers, and Consuls, . . the Supreme Court shall have original jurisdiction." U. S. ConstrTution, Art. III, sec. 2. 
gress, and the law in this regard has passed through three definite stages; exclusive federal jurisdiction prior to 1875 , concurrent state and federal jurisdiction between 1875 and $I 9 I \mathrm{I}$, and exclusive federal jurisdiction subject to an exception, since IgII. Congressional action has been concerned only with prescribing to which courts foreign consuls may be required to answer.

Suits affecting consuls had been included in the Constitution in the original jurisdiction of the United States Supreme Court, ${ }^{\overline{3}}$ but in order to keep minor cases from taking up the time of the Supreme Court ${ }^{6}$ Congress in I789 supplemented the provision in the Constitution with a statute giving the federal district courts concurrent original jurisdiction with the Supreme Court over all suits against consuls and vice-consuls. ${ }^{\top}$ This jurisdiction was expressly made exclusive of the state courts, ${ }^{8}$ and those state courts which had to deal with attempts to bring consuls before them as defendants prior to the first declaration of the United States Supreme Court on the question accepted this lack of jurisdiction almost without question. ${ }^{9}$ The position taken by these courts accorded with the opinion of Attorney General Wirt in 1820 when called upon to interpret Section 9 of the Act of 1789 providing for jurisdiction over suits against consuls and vice-consuls. He declared, "Our constitution and laws, contemplating the responsibility of consuls to the jurisdiction of our courts, have provided the tribunals before which they may sue and be sued or be prosecuted; these are the tribunals of the nation, before which, alone, in exclusion of the State courts, consuls are bound to answer." 10

A few years later, in Davis $v$. Packard, ${ }^{11}$ the constitutionality of this statute was questioned before the Supreme Court. The action was against a foreign consul on a recognizance of bail, starting in the New York Supreme Court. The defendant failed to plead the fact that he was ConsulGeneral of Saxony until the case was up on appeal. After the New York court for the correction of errors had denied exemption from jurisdiction on that ground, there was an appeal to the United States Supreme Court which affirmed the constitutionality of exclusive federal jurisdiction over suits against foreign consuls, finding it difficult to understand upon what ground a state court could claim jurisdiction over a civil suit against a consul since "by the Constitution, the judicial power of the United States extends

- See supra note 4.

- Gittings v. Crawford, supra note 3.

${ }_{7}$ I STAT. 73. 77 (1789), 28 U. S. C. A. \$ I4I (1927).

8 Ibid. "And be it further enacted, That the district courts . . . shall also have jurisdiction exclusively of the courts of the several States, of all suits against consuls or vice consuls. . . ."

${ }^{\circ}$ Mannhardt v. Soderstrom, I Binn. 138 (Pa. I806); Commonwealth v. Kosloff, supra note 3; Sartori v. Hamilton, I3 N. J. L. 107 (1832); but see State v. De La Foret, 2 Nott \& McC. 217 (S. C. I820).

${ }_{10}$ I OP. ATT'Y GEN. 406, 412 (1820).

${ }^{\mu} 7$ PET. 276 (U. S. 1833). 
to all cases affecting ambassadors, other public ministers, and consuls, . . . And the judiciary act of 1789 gives the district courts of the United States, exclusively of the courts of the several states, jurisdiction of all suits against consuls and vice-consuls." 12 The Court also mentioned that the act of Congress, being general in its terms, applied to all suits against consuls. Thus the Supreme Court of the United States declared unequivocally for exclusive federal jurisdiction over all suits against consuls and vice-consuls. Five years later ( 1838 ) the constitutionality of the section of the Act of I789 that gave the district courts concurrent jurisdiction with the Supreme Court over suits against consuls was questioned and affirmed. ${ }^{13}$

Even after these decisions there were several attempts to bring actions against constils in state courts, but without success. The state courts following Davis $v$. Packard, held that the exemption from their jurisdiction was not a personal one and could not be waived, and further, that a foreign consul could not avoid federal jurisdiction and allow himself to be sued in a state court by joining in a contract with another person not a consul and thus subjecting himself to joint suit. ${ }^{14}$ It was recognized by both state and federal tribunals that only the latter had jurisdiction over suits against foreign consuls and vice-consuls. ${ }^{15}$

Jurisdiction over actions against consuls was in this settled condition when Congress, by the Act of February I8, $1875,{ }^{16}$ amended the judicial code so that the jurisdiction of the district courts over foreign consuls was no longer expressly exclusive of the state courts. After this amendment it was generally held that the state courts had concurrent jurisdiction with the federal courts over suits against consuls, at least in civil cases. ${ }^{1 \tau}$ However, one state court refused to exercise any such jurisdiction, even after the amendment of 1875 was specifically brought to its attention. ${ }^{18}$ This court considered that it was not necessary for the federal courts to expressly be given exclusive jurisdiction over suits against consuls, but that such

${ }^{12}$ Ibid. at $28 \mathrm{I}$.

${ }^{13}$ Gittings v. Craw ford, supra note 3.

14 The exemption enjoyed by a foreign consul from the jurisdiction of the state courts belongs to the government he represents. Davis v. Packard, supra note II; Ex parte Gruber, 269 U. S. 302, 46 Sup. Ct. I12 (1925); Miller v. Van, Loben Sels, 66 Cal. 34I, 5 Pac. 5I2 (I885); Durand v. Halbach, I Miles 46 (Pa. 1835); and he cannot waive it by failing to answer in chief, Taaks v. Schmidt, I9 How. Pr. 413 (N. Y. I860), or by failing to plead it, Miller v. Van Loben Sels, supra; Wilcox v. Luco, II8 Cal. 639, 45 Pac. 676 (I896), or by being joined as defendant with others not entitled to the privilege, Valarino v. Thompson, 7 N. Y. 576 ( 1853$)$; and like any other consular privilege it may be taken advantage of for the first time on appeal, Miller v. Van Loben Sels, supra, or at any other stage of the proceedings, Valarino v. Thompson, supra; Hunstiger v. Kilian, I30 Minn. 538, 153 N. W. 1095 (1915).

${ }_{25}$ Sagory v. Wissman, supra note 3; McKay v. Garcia, 6 Ben. 556, Fed. Cas. No. 8844 (S. D. N. Y. I873) ; Sartori v. Hamilton, supra note 9; Valarino v. Thompson, supra note I4; Matter of Aycinena, I Sand. 690 (N. Y. I848).

${ }^{26}$ I8 Stat. 316,318 (1875), 28 U. S. C. A. $\$ \$ 772,37$ I (1928).

${ }^{17}$ In re Iasigi, 79 Fed. 75 I (1897) ; Bors v. Preston, III U. S. 252, 4 Sip. Ct. 407 (1884); De Give v. Grand Rapids Furniture Co., 94 Ga. 605, 2I S. E. 582 (I804) ; Note (I899) 45 L. R. A. 579,582 .

${ }^{18}$ Miller v. Van Loben Sels; Wilcox v. Luco, both subra note I4. 
jurisdiction was inherent in the federal courts because under our system the federal government is the only sovereign having relations with foreign countries, and accordingly all dealings with the representatives of those nations should be by the courts or other agencies of "the government which is alone sovereign in that regard". Most state courts, however, continued to exercise concurrent jurisdiction with the federal courts over suits against consuls until I $9 \mathrm{II}^{19}{ }^{19}$

In that year exclusive jurisdiction over suits against foreign consuls was restored to the federal courts by Section 256 of the Judicial Code. ${ }^{20}$ The new provision for exclusive federal jurisdiction appears to be even broader than that originally granted by the Act of $I 789$, because the present statute gives the federal courts exclusive jurisdiction over "all proceedings" as well as over "all suits" against consuls.

Until recently there seems to have been only one case involving this section of the Judicial Code. In Higginson v. Higginson, ${ }^{21}$ decided in I9I6, the New York Supreme Court held that it had no jurisdiction over an action against a foreign consul for separation, even though the suit was brought under a provision of the state code of civil procedure. The court treated Section 256 of the Judicial Code as expressly restoring the "former exclusive jurisdiction of the district courts over all civil actions against consuls". Thus it was held that the effect of Section 256 of the Act of I9I I was to divest the state courts of all jurisdiction over consuls or their property, ${ }^{22}$ that is, that things were restored to the same position as between I 789 and 1875 .

There seems to be no apparent reason why the intervening period of concurrent state and federal jurisdiction over suits against consuls, between

${ }^{10}$ For a good statement of the law on jurisdiction over suits against foreign consuls between I875 and I9II, see De Leon v. Walters, I63 Ala. 499, 50 So. 934 (I909).

co "The jurisdiction vested in the courts of the United States in the cases and proceedings hereinafter mentioned shall be exclusive of the courts of the several States: . . Eighth. Of all suits and proceedings against ambassadors, or other public ministers, or their domestics, or domestic servants, or against consuls or vice-consuls." 36 STAT. IO87, II60 (I9II), 28 U. S. C. A. \$ 37 I (Ig27).

${ }_{a \mathrm{i}} 96$ Misc. $457,158 \mathrm{~N}$. Y. Supp. 92 (1916). This case gives a good review of the history of jurisdiction over foreign consuls in the United States.

This question of jurisdiction had already been decided in New York under the Act of 1789, Valarino v. Thompson, stipra note 14 , and a portion of the earlier decision was quoted as controlling in Higginson $v$. Higginson, the court quoting Valarino v. Thompson to the effect that, "The defendant, therefore, is exempted as a consul from liability to be sued in the state courts. But this exemption is neither his personal privilege nor the privilege of the state by which he was commissioned. It is not founded on the law of nations, or on any treaty between his government and that of this country. If it can be regarded as a privilege belonging to him or to his office, it is only because it secures to him the protection of the national government, which is responsible to his own for any violation of his rights derived under the law of nations or from treaty. But it does not exempt him from liability to respond to his creditors, or to answer for his misconduct. Nobody denies the liability of a consul to be sued in a civil action. The act of congress concedes it, and provides for it. It prescribes the tribunal in which a consul in this country is to be called on to answer, and excludes the state courts from jurisdiction. The object of this exclusion was to keep within the control of the federal government, and subject to the authority of its courts, all cases and controversies which might in any degree affect our foreign relations."

${ }^{\circ}$ Puente, op. cit. silpra note $\mathrm{I}$, at 456 . 
I875 and I9II, should change the results now to be reached under the statute. However, when the wife of the Roumanian consul in Cleveland, Ohio, brought suit in a federal district court for a divorce ${ }^{23}$ the action was dismissed on the ground that the federal courts have no jurisdiction over an action for divorce and alimony, even when against a foreign consul. The court admitted that if the action had been one of first impression it would have inclined toward taking jurisdiction, but refused to do so because “. . . it would be presumptuous for an inferior court to announce a conclusion adverse to that clearly stated by the Supreme Court . . ." The conclusion referred to was the dicta in Barber v. Barber ${ }^{24}$ that, "We disclaim altogether any jurisdiction in the courts of the United States upon the subject of divorce. . . ." The district court in Popovici v. Popovici, referring to this same decision, declared, "It will be presumed that the Supreme Court had in mind and appreciated the full extent of its statutory jurisdiction." But it must be noted, as will be discussed later, that Barber v. Barber did not involve a foreign consul, was not an action for divorce, and that the statement here relied upon was purely dictum. The district court's decision in Popovici v. Popovici was contrary to what had been expected and predicted would be the result in such a case if it should arise. ${ }^{25}$

Following the dismissal of Popovici v. Popovici in the federal district court, the plaintiff brought action in an Ohio state court in reliance upon the federal court's opinion as to the proper jurisdiction. The defendant, as a foreign consul, sought a writ of prohibition from the Ohio Supreme Court on the ground of lack of jurisdiction in the state court under Section 256 of the Judicial Code. The writ was denied, the Ohio Supreme Court apparently being much impressed by the fact that "Congress has not at any time established a special court, or given jurisdiction to the District Courts over causes involving domestic relations affecting foreign ministers and consuls." 26 It might well be, however, that that part of Section 250 of the Judicial Code which gives the district courts jurisdiction, exclusive of the state courts, "of all suits and proceedings . . . against consuls and viceconsuls" was intended to include divorce actions against them, especially in view of the fact that the statute was phrased so broadly.

\footnotetext{
${ }^{23}$ Popovici v. Popovici, 30 F. (2d) 185 (D. C. Ohio I927); see also (1929) $38 Y_{\text {ALE }}$ L. J. 990 .

es See 2I How. 582, 584 (U. S. 1859).

25 Rose, in discussing the general rule against federal jurisdiction over divorce, suggested that "it is possible to conceive of a proceeding for divorce in which a District Court would have original jurisdiction, provided the defendant is a consul of a foreign State." Rose, Federal Jurisdiction and Procedure (4th ed. I93I) § I89. While Dobie, in reference to exclusive federal jurisdiction over foreign consuls, says, "The jurisdiction of the federal courts over such cases is made exclusive of the state courts, and this is constitutional. So that a wife cannot sue hen husband, who is a consul of a foregn country for a statutory separation in the state courts." DobIe, Federal Frocedure (I928) 258.
}

${ }^{20}$ Ohio ex rel. Popovici v. Alger et al., Judges, I I9 Ohio St. 484, 49I (I928). 
On appeal to the United States Supreme Court, Ohio ex rel. Popovici v. Alger et al., Judges, ${ }^{27}$ the appellant alleged that he was the Roumanian vice-consul stationed at and residing in Cleveland, Ohio. He denied the jurisdiction of the state court over the action, invoking Article III, Section 2 , of the Constitution, and also Sections 24 and 256 of the Judicial Code ${ }^{28}$ which give original jurisdiction to the federal district courts, concurrently with the Supreme Court and exclusively of the state courts, over suits and proceedings against foreign consuls and vice-consuls. The Supreme Court, speaking through Mr. Justice Holmes, affirmed the Ohio court's decision, holding that the whole subject of the domestic relations of husband and wife, parent and child, belonged to the laws of the states and not to the laws of the United States, that the jurisdiction of the courts of the United States over divorce and alimony has always been denied, that the statutes did not affect the present case "if it be true as has been unquestioned for three-quarters of a century that the Courts of the United States have no jurisdiction over divorce", and that the phrase in the Judicial Code about "suits against consuls and vice-consuls" must be taken as referring to "ordinary civil proceedings and not to include what formerly belonged to the ecclesiastical Courts". In other words, the Act of IgII was construed as not wholly excluding the state courts from jurisdiction over suits against consuls. ${ }^{29}$

Thus this decision involved a conflict between two jurisdictional principles: one, based on the Constitution, on statutes, and on public policy, and supported by both state and federal decisions, that the federal courts have exclusive jurisdiction over all suits and proceedings against consuls and viceconsuls; the other, that the federal courts have no jurisdiction whatever over domestic relations, particularly over divorce and alimony. This conflict was resolved by subjecting the exclusive jurisdiction of the federal courts over suits against consuls, to an exception in favor of state jurisdiction over domestic relations, even though the latter doctrine appears to be entirely judge-made.

\section{The Federal Courts and Divorce}

The federal courts could have no jurisdiction over any ordinary action for divorce even if this alleged lack of federal jurisdiction over the subject matter of domestic relations were disregarded. The obstacle would be lack of jurisdiction over the parties themselves. This is illustrated by two attempts that were made to bring divorce actions in federal district courts, both of which failed. One was an original action for divorce which the federal court refused to entertain because there was neither the requisite

${ }^{23} 36$ STAT. IO9I, II60 (I9II), 28 U. S. C. A. \$\$ 4I, 37 r.

eo (I930) 43 Harv. L. Rev. 822. 
diversity of citizenship nor any federal question involved, nor any other basis for federal jurisdiction over the parties. ${ }^{30}$ The other was an attempt to remove a divorce action from a state court to a federal court, the defendant alleging that there had been no marriage at all, and that therefore diversity of citizenship existed as he and the plaintiff were citizens of different states. The amount asked as alimony being sufficiently large, the defendant claimed that the requirement of jurisdictional amount was satisfied. But the federal court held ${ }^{31}$ that there was no basis for removal here, since if the decision was for the plaintiff that there had been a marriage, then the court would have no jurisdiction as there would be no diversity of citizenship. This was when a wife's citizenship necessarily followed that of her husband. Another ground for the refusal of the court to allow removal was that the amount of alimony to be granted depends not at all upon the amount asked for by the plaintiff, but on the contrary is entirely at the discretion of the court, and that therefore the amount in controversy was uncertain and the statutory requirement of a sufficient jurisdictional amount was not satisfied. Neither of these cases can be regarded as any authority for the principle that the federal courts have no jurisdiction over the subject matter of divorce and alimony. They were dismissed on the completely independent grounds of no diversity of citizenship, no federal question, and insufficient jurisdictional amount, all of which pertain to lack of jurisdiction over the parties and not to lack of jurisdiction over the subject matter.

Before the decision of the Supreme Court in Ex rel. Popovici v. Alger it was not doubted but that a proper divorce action could get into the federal courts, and, since the Act of September 22, 1922, ${ }^{32}$ regarding the citizenship of married women, the only obstacle to the entertaining of a divorce suit in the federal courts, provided the requisite diversity of citizenship existed, was thought to be the fact that the amount in controversy could not be reduced to a definite sum in order to satisfy the requirement for a jurisdictional amount. ${ }^{33}$

The only grounds for federal jurisdiction over an action for divorce against a foreign consul would be either diversity of citizenship, or the mere fact that it would be a "suit or proceeding against a foreign consul". But the first has just been shown to be unavailable, even assuming the actual existence of diverse citizenship between the consul and his wife-a question that might involve the laws of the consul's home country as well as those of the United States-because of the provision in the Judicial Code that in diversity cases the district courts shall have original jurisdiction only when the matter in controversy, exclusive of interest and costs, exceeds the sum

${ }^{30}$ Johnson v. Johnson, I3 Fed. 193 (C. C. S. D. N. Y. I882).

31 Bowman v. Bowman, 30 Fed. 849 (C. C. N. D. I11. I887).

${ }^{32} 42$ STAT. I02I, I022 (I922), 8 U. S. C. A. $\$ \$ 367,368$ (I927).

${ }^{33}$ Rose, op. cit. supra note $25, \S \mathrm{I} 55$, at 169 . 
or value of $\$ 3000,{ }^{34}$ and the amount in controversy in a divorce action is uncertain and therefore insufficient to satisfy the statute. ${ }^{35}$ But this difficulty of a jurisdictional amount does not arise under the Section of the Judicial Code which gives exclusive jurisdiction over consuls to the federal courts, as it is expressly provided that the requirement as to the sum or value of the matter in controversy shall not be construed to apply to suits or proceedings against consuls or vice-consuls. ${ }^{36}$

This leaves as the only obstacle to federal jurisdiction over a divorce action against $a$ foreign consul the principle that the federal courts will not take jurisdiction over any action for divorce or alimony. The Supreme Court in Ex rel. Popovici v. Alger relied upon In re Burrus, ${ }^{37}$ Barber v. Barber, ${ }^{38}$ Simms v. Simms, ${ }^{39}$ and De La Rama v. De La Rama, ${ }^{40}$ as establishing this "hands off" doctrine.

In re Burrus was cited as authority for the general principle that the subject matter of domestic relations is not within the jurisdiction of the federal courts. There was no question of divorce involved in that case, and what was actually held there was that a district court has no authority in law to issue a writ of habeas corpus to restore an infant to the custody of its father, when unlawfully detained by its grand-parents. There was no basis for federal jurisdiction because there was no federal question involved and no other grounds for jurisdiction were alleged. But the court made the declaration that "the whole subject matter of the domestic relations of husband and wife, parent and child, belongs to the laws of the states, and not to the laws of the United States." 41 This statement was not necessary to the decision and must be regarded as mere dictum. However, it should also be noted that the court did not say that the "whole subject of domestic relations" was one that did not belong to the federal courts, but only that it was a subject for the lawe of the states. Accordingly there would seem to be no reason why it would not be in accord with this decision for a federal court to take jurisdiction of a domestic relations case if proper jurisdictionalfacts were alleged, such as that the defendant is a foreign consul, and then proceed to apply state law. It is not true that the courts of the United States will refuse to take jurisdiction over any cases which require them to pass upon questions of law peculiarly within the control of the states. The states regulate, as they will, titles to the lands within their boundaries, and all questions of real property law are governed by them. Yet the federal

${ }^{34} 36$ STAT. IogI, par. I (IgII), 28 U. S. C. A. § 4I, par. I (I927).

ss Bowman v. Bowman, supra note $3 \mathrm{I}$.

is 36 STAT. I093, par. I (I8) (I9II), 28 U. S. C. A. $\$ 4$ I, par. I (I8) (1927).

s 136 U. S. 586, 10 Sup. Ct. 850 (I890).

${ }^{39} 21$ How. (62 U. S.) 582 (1856).

${ }^{30}$ I75 U. S. I62, 20 Sup. Ct. 58 (I899).

${ }^{10} 201$ U. S. 303, 26 Sup. Ct. 485 (I906).

a Supra note 37 , at 593 , 1o Sup. Ct. at 853 . 
courts have never considered that fact as any reason why they should not take jurisdiction over an ejectment case where the parties to it are of diverse citizenship. ${ }^{42}$ Speaking generally, the federal courts, when their jurisdiction is properly invoked, enforce state laws precisely as do the state courts under similar circumstances. For the particular case they function as if sitting in the place of the state court. ${ }^{43}$ Rights created and remedies provided by state statutes to be pursued in state courts may be administered in the federal courts whenever the proper jurisdictional facts are alleged. ${ }^{44}$ This rule has actually been applied by the federal courts in cases where the only basis for federal jurisdiction was the fact that the defendant was a foreign consul, ${ }^{4 \pi}$ and it is arguable that such a procedure should have been followed in Popovici v. Popovici. Looked at in the light of these facts, In re Burrus is weak authority for lack of federal jurisdiction over domestic relations whenever any independent grounds exist on which to base jurisdiction.

The other three cases, Barber v. Barber, Simms v. Simms, and De La Rama $v$. De La Rama, were relied upon as establishing the specific proposition that "the jurisdiction of the Courts of the United States over divorces and alimony has always been denied."

Barber $v$. Barber contains the first declaration of a federal court on this subject, and is perhaps the strongest basis for this doctrine of no federal jurisdiction over divorce and alimony. In that case a federal court enforced an alimony decree already obtained in a state court, basing its jurisdiction on diversity of citizenship of the parties, the requisite jurisdictional amount being involved. This was reversed on appeal to the Supreme Court. In its opinion the Supreme Court states, "We disclaim altogether any jurisdiction in the courts of the United States upon the subject of divorce, or for the allowance of alimony, either as an original proceeding in chancery or as an incident to a divorce $a$ vinculo, or to one from bed and board." 46 This remark was entirely obiter, since the issue of the case was solely that of enforcing a New York alimony decree as a debt of record; but it is from this declaration that has arisen the doctrine of no federal jurisdiction over the subject matter of divorce, even where proper facts are alleged to give the federal courts jurisdiction over the parties.

Simms v. Simms and De La Rama v. De La Rama scarcely bear out the statement of the Supreme Court that the federal courts have no jurisdiction over the subject matter of divorce. Both were divorce actions, the

${ }^{42}$ Rose, op. cit. supra note $25, \S \mathrm{I} 85$, at 193 .

${ }_{43} 28$ U. S. C. A. \& 4I (I), note 7, p. 50; see also the cases cited in Grover v. Merritt Development Co., 7 F. (2d) 9I7 (D. C. Minn. 1925).

"Harrison v. Remington Paper Co., 140 Fed. 385 (C. C. A. 8th, 1905), 3 L. R. A. (N. s.) 954 (1905); Platt v. Lecocq, I58 Fed. 723 (C. C. A. 8th, 1907), I5 L. R. A. (N. s.) 558 (I908).

${ }_{45}$ McKay v. Garcia, supra note 15.

${ }^{18}$ Supra note 38 , at 584 . 
first arising in the Arizona Territory, the second in the Philippines; both came up to the United States Supreme Court on appeal. The general rule of Barber v. Barber was held to have no application to the territorial courts, nor to the appellate jurisdiction of the Supreme Court. It would seem to follow, therefore, that there is nothing inherent in the subject matter of divorce that should remove it from federal jurisdiction if the parties are properly before the court. The fact that these two cases arose where Congress had entire dominion and authority does not impair the significance of the decision of the Supreme Court in each of them, sustaining its jurisdiction over divorce actions when an independent ground for that jurisdiction existed.

As was mentioned before, there was no attempt by the Supreme Court in Barber v. Barber to show any basis or reason for the statement disclaiming jurisdiction in the federal courts over the subject of divorce and alimony. Apparently the only effort that has been made by the Supreme Court to rationalize and justify that declaration appears in De La Rama v. De La Rama, where the court says it has been a long established rule that the courts of the United States have no jurisdiction over the subject matter of divorce and alimony, "both by reason of the fact that the husband and wife cannot usually be citizens of different states so long as the marriage relation continues, and for the further reason that a suit for divorce in itself involves no pecuniary value." 47 These, as has been discussed, are very good reasons why the federal courts should not have jurisdiction over the ordinary divorce case, but are no bar to the exercise of that jurisdiction when it exists on some other basis than that of diversity, as was considered to be the case in Simms v. Simms and De La Rama v. De La Rama, and might well have been found to be the case in Ohio ex rel. Popovici $v$. Alger. The doctrine appears not to have been followed whenever there was a basis for jurisdiction over the parties, with the exception of the latter case.

In reference to the provisions in the Constitution and in the Judicial Code for exclusive federal jurisdiction over all suits and proceedings against consuls and vice-consuls, the Supreme Court in Ex rel. Popovici admits that, "The language so far as it affects the present case is pretty sweeping, but like all language it has to be interpreted in the light of the tacit assumptions upon which it is reasonable to suppose that the language was used." The so-called "tacit assumption" was the "hands off" doctrine concerning federal jurisdiction over divorce; but there is nothing to show that Congress in the Act of IgI I did not use the word "all" in its literal sense. The court points out, citing Plaquemine Tropical Fruit Co. v. Henderson, ${ }^{48}$ that the words quoted from the Constitution "do not of themselves and without 
more exclude the jurisdiction of the State". But here there is "more" in the form of Article 256 of the Judicial Code expressly excluding the state courts from jurisdiction. The Supreme Court justified its deviation from the clear words of this statute by the argument that, "the statutes do not purport to exclude the State Courts from jurisdiction except where they grant it to the Courts of the United States. Therefore they do not affect the present case if it be true as has been unquestioned for three-quarters of a century that the Courts of the United States have no jurisdiction over divorce. If when the Constitution was adopted the common understanding was that the domestic relations of husband and wife and parent and child were matters reserved to the states, there is no difficulty in construing the instrument accordingly and not much in dealing with the statutes. 'Suits against consuls and vice-consuls' must be taken to refer to the ordinary civil proceedings and not to include what formerly would have belonged to the ecclesiastical Courts." Exactly the opposite reasoning would have resulted had the principle of statutory interpretation laid down in Goldsmith $v$. Holmes ${ }^{49}$ been adhered to. There the United States Supreme Court affirmed the decision of a district court that "the law conferring jurisdiction on the federal courts is not to be strictly construed; for the jurisdiction is presumably a beneficial one."

It has been held that if the provisions of a statute are plain and unambiguous the courts should not read into it exceptions or limitations which depart from its plain meaning. ${ }^{50}$ And of the specific statute here in question, it has been declared that not only is it constitutional, but its provisions are so clear as to leave no room for any construction involving limitations or exceptions. ${ }^{51}$ It is submitted that the requirements for exclusive federal jurisdiction in Ex rel. Popovici, under Article 256 of the Judicial Code, were fully met by the allegation that the defendant was a foreign vice-consul in this country. This contention is supported by the decision of the United States Supreme Court in Illinois Central Ry. Co. v. Adams, ${ }^{52}$ where it was held that the only facts necessary to vest jurisdiction of a controversy in the federal courts are those embodied in the express provisions of the statute by virtue of which such jurisdiction exists.

When powers are given exclusively to the federal courts, or expressly taken away from the states, or the exercise of them by the state courts would be incompatible with the power given the federal courts, the state courts are excluded from jurisdiction. ${ }^{53}$ All these conditions appear to be satisfied in Ex rel. Popovici. Article 256 of the Judicial Code expressly

${ }^{49}$ I47 U. S. 150, 13 Sup. Ct. 288 (1893), aff'g 36 Fed. 484 (C. C. Ore. 1888), r L. R. A. $8 \mathrm{I} 6$ ( 1888 ).

${ }_{50}$ Wall v. Pfanschmidt, 265 I1l. 180, 106 N. E. 785 (1914).

${ }^{51}$ Puente, op. cit. supra note I, at 456 .

${ }^{2}$ I80 U. S. 28, 2 I Sup. Ct. 25 I (I90I).

${ }^{2}$ I Kent's Conis. (12th ed. I873) *396. 
gives the federal courts exclusive jurisdiction over all suits and proceedings against foreign consuls and vice-consuls, expressly takes that jurisdiction away from the state courts, and the exercise of any such jurisdiction by the state courts is incompatible, at least on the ground of public policy, with the power given to the federal government and the federal courts.

As to the statement in Ex rel. Popozici that the statutes relied upon by the defendant consul to show lack of state jurisdiction did not affect the case "if it be true as has been unquestioned for three-quarters of a century that the Courts of the United States have no jurisdiction over divorce", it need only be pointed out that no divorce case arose in the federal courts during that period in which there was any basis for federal jurisdiction over the parties, and that in the one state case directly in point, Higginson $v$. Higginson, ${ }^{54}$ the state court could perceive no obstacle to federal jurisdiction over divorce where the federal court would have jurisdiction over the parties. This same state court referred to a divorce suit as a "civil action", while in Ex rel. Popovici the Supreme Court inferred that divorce proceedings were something not within the category of civil actions, saying, "Suits against consuls and vice-consuls' must be taken to refer to ordinary civil proceedings and not to include what formerly would have belonged to the ecclesiastical Courts." However, in the United States we do not have the old English system of ecclesiastical jurisprudence. Our courts of equity, both state and federal, have taken over what formerly belonged to the ecclesiastical courts, ${ }^{55}$ the federal courts being granted their equity powers by the Constitution itself.56 Also it is quite possible that it was the "common understanding" at the time the Constitution was adopted, not only that domestic relations were a matter for the states, but also that anything touching foreign representatives in this country, including consuls and vice-consuls, was a matter for the federal government and the federal courts.

\section{Federal Policy Concerning Jurisdiction Over Foreign Consuls}

The immunity of consuls from the jurisdiction of the state courts has been granted not by treaty, but by statute, as a matter of policy by the government of the United States, "to the end that our foreign relations may not be embarrassed by subjecting recognized consuls to prosecution by the state courts. Consuls are accepted and expelled by the federal government and not by the state government, and, therefore, while lawfully acting and representing the sovereignty from which they received their appointment they are very properly made subject to prosecution only in the federal courts." 57 It is proper that the federal courts should have exclusive juris-

4 96 Misc. 457,158 N. Y. Supp. 92 (1916).

* RodGers, DoMestic Relations (I899) \& 28, p. 19.

$\approx$ U. S. Constitution, Art. III, Sec. 2.

"Tavic v. City of New York, 203 App. Div. 8I, 196 N. Y. Supp. 422 (I922). 
diction over suits against consuls and vice-consuls because when the states adopted the federal constitution they conferred upon the federal government the privilege of exercising a portion of the judicial power formerly belonging to them, with the intention of making the judicial authority of the federal government co-extensive with its political powers. ${ }^{5 s}$ The federal government has exclusive charge of our foreign relations, and of all political intercourse between this country and others; Article 256 of the Judicial Code, and Article III, Section 2, of the Constitution should be interpreted accordingly. The objects of this exclusion of the state courts from jurisdiction over suits against consuls were: to prevent the harassing of such foreign representatives in the state courts, ${ }^{59}$ to prevent them from being hindered in the exercise of their functions, and to keep within the control of the federal government and subject to the authority of the federal courts all controversies which might in any way affect our foreign relations. ${ }^{60}$ The federal government is interested in maintaining the exclusiveness of this jurisdiction "for the purpose of preventing it from being involved in controversies with foreign powers without its consent, and for acts not its own". ${ }^{61}$ As one court puts it, "Under our system, the government of the United States is the only sovereign having relations with foreign countries under the law of nations; and all dealings with the representatives of foreign nations must be by the courts or other agencies of the government which is alone sovereign in that regard." 62

Among other reasons, consuls should be subject only to federal jurisdiction because they are the public agents of foreign nations, having many important duties to perform. They constitute a link in the chain of our foreign relations which ought not to be broken by the interference of state authority, for in case of any dispute, the foreign state would look to the federal government for the redress which federal authority should be in a position to afford through its power to interfere in the prosecution of suits in the federal courts. ${ }^{63}$ The Supreme Court of the United States has itself expressed the view, with reference to the constitutional provision for federal jurisdiction over consuls, that, "Higher considerations of public policy doubtless led to the provision; it was deemed fit and proper, that the courts of the government, with which rested the regulation of all foreign intercourse, should have cognizance of suits against the representatives of such foreign governments." ${ }^{64}$.

\footnotetext{
${ }^{28}$ Valarino v. Thompson, supra note $\mathrm{I} 4$.

${ }^{\text {to }}$ Matter of Aycinena, supra note 15.

${ }^{\infty}$ Valarino v. Thompson, supra note I4.

" Popovici v. Popavici, supra note 23 , at 186 .

Wilcox v. Luco, supra note 14, at 647,45 Pac. at 676 (1896).

s State v. De La Foret, supra note 9, dissenting opinion.

a Davis v. Packard, supra note II, at 283 .
} 
It is apparent that there are strong arguments of policy against the decision in Ohio ex rel. Popovici v. Alger, and considerable reason to question the soundness of the doctrine that the federal courts have no jurisdiction over the subject matter of divorce and alimony. It might be advisable, because of the policy involved, for Congress to amend Section 256 of the Judicial Code to expressly extend the exclusive federal jurisdiction over suits against consuls to include all possible cases; but until that may be done it must be recognized that there is an exception. The federal courts now have jurisdiction over all suits and proceedings against consuls and viceconsuls to the exclusion of the state courts only where the jurisdiction of the subject matter has been vested in the federal courts. ${ }^{65}$ This exception seems to include nothing other than cases involving the domestic relations of consuls and vice-consuls, but it may conceivably be found to include more. ${ }^{66}$

“ Dickinson, Casfs on the Law of Natrons (xst ed. Ig2g, 2d impression) 593, n. 33.

os See also Note (1930) 28 Mich. L. Rev. 59I, (I930) 78 U. OF PA. L. Rev. 665, and (I930) 43 HaRv. L. REv. 822 . 